10 - ORIGINAL ARTICLE EFFECTS OF DRUGS

\title{
Effect of letrozole in carcinogen-plus-estrogen-induced endometrial hyperplasia in mice ${ }^{1}$
}

\author{
Alessandra Cerávolo Lara', Eduardo Batista Cândido ${ }^{I I}$, Paula Vieira Vidigal ${ }^{\mathrm{III}}$, Ana Luiza Lunardi Rocha ${ }^{\mathrm{IV}}$, Alessandra Costa \\ Carvalho-Macedo ${ }^{I v}$, Márcia Mendonça Carneiro ${ }^{I v}$, Agnaldo Lopes Silva-Filhov
}

DOI: http://dx.doi.org/10.1590/S0102-865020160040000010

IMaster, Department of Obstetrics and Gynecology, Universidade Federal de Minas Gerais (UFMG), Belo Horizonte-MG, Brazil. Design and supervise all phases of the study, analysis of data, manuscript writing.

${ }^{\text {II } P h D, ~ D e p a r t m e n t ~ o f ~ O b s t e t r i c s ~ a n d ~ G y n e c o l o g y, ~ U F M G, ~ B e l o ~ H o r i z o n t e-M G, ~ B r a z i l . ~ A c q u i s i t i o n ~ a n d ~ a n a l y s i s ~ o f ~ d a t a . ~}$

IIIPhD, Department of Pathology, UFMG, Belo Horizonte-MG, Brazil. Acquisition of data, critical revision.

${ }^{\text {IV }} \mathrm{PhD}$, Department of Obstetrics and Gynecology, UFMG, Belo Horizonte-MG, Brazil. Acquisition of data, critical revision.

${ }^{v} \mathrm{PhD}$, Department of Obstetrics and Gynecology, UFMG, Belo Horizonte-MG, Brazil. Design and supervise all phases of the study, analysis of data, manuscript writing.

\begin{abstract}
PURPOSE: To evaluate the effects of letrozole (Ltz) in carcinogen+estrogen-induced endometrial hyperplasia.

METHODS: BALB/c female mice were divided into four groups of 12 animals each receiving an intrauterine dose of N-ethyl-Nnitrosourea (ENU) and weekly subcutaneous injections of estradiol hexaidrobenzoate (EHB), except for group I(control). The groups were divided in I (control), II (ENU+EHB), III (ENU+EHB+MPA) and IV (ENU+EHB+Ltz). Group III also received intramuscular injections of MPA (medroxy progesterone acetate) every four weeks, while group IV received oral doses of Ltz daily. At the end of 16 weeks, the animals were sacrificed, and blood samples were collected for the measurement of serum estradiol and progesterone levels. Uterine histological sections were made to evaluate the presence of endometrial proliferative lesions. Differences between groups were evaluated with student's $t$ test, ANOVA and chi-square test.

RESULTS: Groups ENU+EHB, ENU+EHB+MPA and ENU+EHB+Ltz showed varying degrees of endometrial hyperplasia. The incidence of hyperplasia in groups ENU+EHB and ENU+EHB+Ltz was higher and more severe than in group ENU+EHB+MPA. Control group showed lower levels of serum estradiol than the other groups.

CONCLUSION: There was no evidence that letrozole could act as an antiestrogenic drug in the development of endometrial proliferative lesions.
\end{abstract}

Key words: Endometrial Hyperplasia. Estradiol. Progesterone. Mice. 


\section{Introduction}

Endometrial hyperplasia represents a nonphysiological, noninvasive proliferation of the endometrium that results in a morphologic pattern of glands with irregular shapes and varying size $^{1}$. There are two forms of hyperplasia, one (atypical) that is closely related to adenocarcinoma, being an apparent precursor lesion, and another (nonatypical) that is largely self-limited with little apparent relationship to carcinoma².

Acording to World Health Organization (WHO), the endometrial hyperplasia is classified in nonatypical hyperplasias (typical) - simple hyperplasia without atypia, complex hyperplasia without atypia - and atypical hyperplasias - simple atypical hyperplasia and complex atypical hyperplasia. Correct identification and classification of hyperplasia are especially important in endometrial biopsy and curettage specimens because proper diagnosis guides clinical therapy ${ }^{3}$, which can be very different depending on the type of hyperplasia found. This pathologic entity is detected in up to $25 \%$ of women with abnormal bleeding that were submitted to diagnostic hysteroscopy ${ }^{4-6}$. The atypical hyperplasias presents a higher risk for adenocarcinoma progression and, in $40 \%$ of cases, it can occur with concomitant invasive neoplasia?

The endometrium is a hormone-dependent tissue and a high percentage of endometrial tumors express estrogenic and/ or progestagenic receptors. Estrogen promotes endometrial proliferation, whereas progesterone inhibits this proliferation ${ }^{8}$. The progesterone-induced estrogen-opposed effect is obtained through the reduction of cellular receptors to estrogen and through the induction of target-cell enzymes that convert estradiol into estrone sulfate, an excreted metabolite. Consequently, the number of estrogenic receptor complexes that are retained in the cell nuclei is decreased, such as estradiol intracellular viability. In addition, progestagenic agents suppress estrogenic-induced oncogenetic transcription ${ }^{8}$.

Progestins, which are synthetic derivatives of progesterone that have antiestrogenic activity after binding to partial response, have been used for patients with endometrial tumors. The efficacy of megesterol acetate and medroxyprogesterone acetate for patients with advanced endometrial tumors has been reported for relatively short periods ${ }^{9,10}$. In previous studies including 30 patients treated with hormonal therapy in which 28 patients were treated with medroxyprogesterone acetate, 24 patients $(80 \%)$ were classified as complete response, partial response, or stable disease ${ }^{11}$. It should be noted that long-term use of high-dose progestin therapy is associated with adverse effects such as weight gain, severe depression, and thromboembolic complications ${ }^{12}$.
Aromatase inhibitors were developed as therapeutic effectors for estrogen-dependent cancers and are being used in malignant breast tumors in post-menopausal patients ${ }^{13}$.

Aromatase inhibitors can reduce the levels of estrogen by inhibiting estrogen synthesis in peripheral sites, which leads to a reduction in the receptor-mediated growth stimulated in estrogen receptors-positive tumors. Aromatase inhibitors are therefore well known as key drugs for estrogendependent breast cancers. Firstand second- generation Aromatase inhibitors are associated with serious adverse effects due to the inhibition of mineralocorticoid and glucocorticoid syntheses. The third-generation Aromatase inhibitors are more efficacious because they are highly selective competitive inhibitors of the aromatase enzyme and have little effects on the adrenal glands. They can also be administered orally ${ }^{14}$. There are two broad categories of thirdgeneration AIs. The reversible nonsteroidal agents include letrozole and anastrozol. In contrast, exemestane is an androstenedione derivative that functions as an irreversible steroidal inhibitor ${ }^{15}$. The effect of thirdgeneration Aromatase inhibitors has been noted in other fields, and it has been demonstrated that they have superior efficacy compared with tamoxifen as an initial therapy for early breast cancer ${ }^{15}$.

Tests with histocultures of endometrioid endometrial cancer treated with aromatase inhibitors suggest a tumoral estrogen depletion, which could result in decreasing cellular proliferation within tumoral cells ${ }^{16}$. Aromatase is considered a key enzyme for endometrial cancer estrogen synthesis. There is an association between aromatase immunoreactivity in stromal cells and poor prognosis in patients with endometrial carcinoma. However, the mechanism of action of aromatase in this process is largely unknown ${ }^{17}$. Further understanding of the relevance of aromatase and estrogen receptor and their interplay with other growth pathways will be necessary to guide further development of letrozole ${ }^{18}$.

Based on the clinical relevance of endometrial hyperplasias and the necessity of more knowledge about the role of aromatase inhibitors in endometrial carcinogenesis, this study evaluated the effects of letrozole, an aromatase inhibitor, in estrogen+carcinogen-induced endometrial hyperplasia in mice.

\section{Methods}

This experimental study was performed in the Animal Care Service, School of Medicine, Universidade Federal de Minas Gerais (UFMG). The research protocol was approved by the Ethical Committee for Animal Experimentation (CETEA/UFMG). 
We used $48 \mathrm{BALB} / \mathrm{c}$ female mice, 11 weeks old, from CEBIO (Animal Care Center of UFMG, Belo Horizonte, MG, Brazil). The animals were kept in aseptic and ventilated cages at an average temperature of $22^{\circ} \mathrm{C}$ with a 12-h light/dark cycle.

Filtered water and rodent chow (Labina ${ }^{\circledR}$, Purina) were given ad libitum. The average water ingestion was $5 \mathrm{~mL} /$ animal/ day at the beginning of the experiment. Before drug administration, mice were kept for seven days in these conditions for ambient adaptation.

\section{Drugs and vehicles}

N-ethyl-N-nitrosourea (ENU) - Sigma (St Louis, MO), diluted at $1.5 \%$ in polyethylenoglycol (PEG) 4000; Estradiol Hexahydrobenzoate (EHB) - Benzo-ginoestril A.P. ${ }^{\circledR}$ - Aventis, diluted at $50 \mu \mathrm{g} / \mathrm{mL}$ in corn oil; medroxy progesterone acetate (MPA) - Depo-Provera ${ }^{\circledR}$, Pharmacia Brazil $(2 \mathrm{mg} / \mathrm{kg}$ or $0.05 \mathrm{mg}$ per $25 \mathrm{~g}$ of animal) administrated every 4 weeks (weeks 1, 4, 8, 12 and 16); Letrozole (Ltz) - Femara ${ }^{\circledR}$ - Novartis Biosciencies, 2.5 mg tablets, diluted at $3 \mu \mathrm{g} / \mathrm{mL}$ in drinking water; and anesthetics Xylazine and Ketamine.

\section{Experimental model inducing endometrial hyper- plasia}

Drugs were administered via different routes. According to Takahashi et al. ${ }^{19}$, bilateral intrauterine injections of ENU were made using Gelco/Angiocath $45 \mathrm{~mm} / 23 \mathrm{G}$, through the mouse cervix. We used subcutaneous injections for estrogen ${ }^{19,20}$, intramuscular injections for progestagen ${ }^{21}$ and oral administration of letrozole. Female BALB/c mice were treated daily letrozole (10 microg/day) every four weeks ${ }^{22,23}$. Eleven week-old females were weighed and divided into four groups - I, II, III and IV.

The experimental design is illustrated in Table 1 . All the animals received an intrauterine injection of ENU $(12.5 \mathrm{mg} / \mathrm{kg})$ diluted in PEG, under anesthesia (xylazine $0.02 \mathrm{~mL}+$ ketamine $0.04 \mathrm{~mL}$ ), except for group I (control), which received vehicle. Groups II (ENU + EHB), III (ENU + EHB + MPA) and IV (ENU $+\mathrm{EHB}+\mathrm{Ltz})$ received EHB injections weekly $(100 \mu \mathrm{g} / \mathrm{kg})$, group III received MPA injections every 4 weeks (weeks 1, 4, 8, 12 and 16) at $2 \mathrm{mg} / \mathrm{kg}^{23}$, while group IV received Ltz diluted in drinking water at $3 \mu \mathrm{g} / \mathrm{mL}$, according to the recommended dose for humans $(0.6 \mathrm{mg} / \mathrm{kg} / \text { day })^{22,23}$

TABLE 1 - Experimental model and drug administration scheme in mice submitted to the endometrial hyperplasia induction.

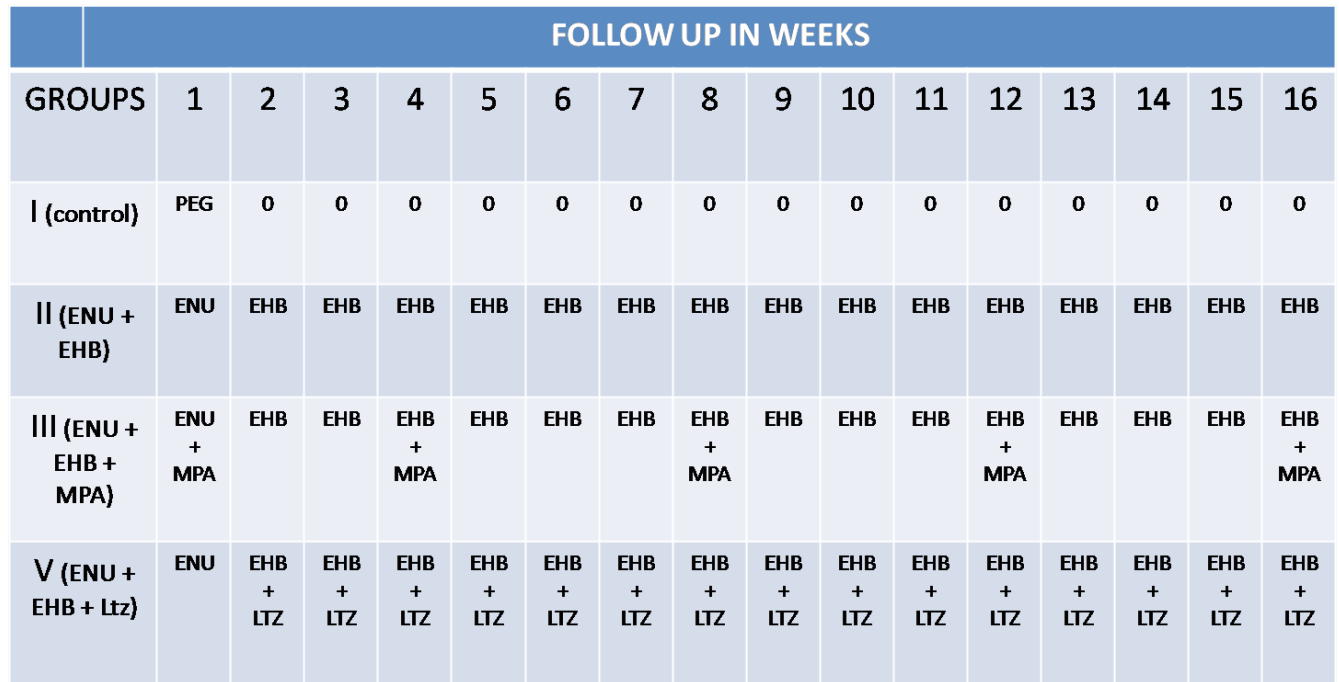

$\boldsymbol{\nabla}=\mathrm{PEG}$ (intrauterin); $\mathrm{O}=$ maize oil (subcutaneous); $\mathrm{C}=\mathrm{ENU}+\mathrm{PEG}$ (intrauterin); $\mathrm{E}=\mathrm{estrogen}$ (subcutaneous); $\mathrm{P}=$ progestagen (intramuscular); Ltz=Letrozole (oral).

\section{Obtaining blood and tissue samples}

Sixteen weeks after ENU administration, the animals were anesthetized again; blood samples were obtained by medial orbital sinus puncture and then sacrificed by cervical dislocation and necropsied. Blood samples were immediately centrifuged and serum was kept at $-20^{\circ} \mathrm{C}$ until processing. Uteri were resected and fixed in a $10 \%$ buffered formalin solution for posterior histological analysis.

\section{Hormone quantification}

Serum samples were analyzed for estradiol (E2) levels, by electrochemiluminescence and chemiluminescence, respectively. Hormone levels were expressed by pg/mL (E2).

\section{Histological studies}

After formalin fixation, uterus samples were embedded in paraffin; the slices were stained in hematoxilin and eosin (H\&E). 
For each whole uterus (including cervix), we obtained transverse slices; histological analysis was performed by a pathologist physician who did not know the animal group identification (a blind study).

Endometrial proliferative lesions were classified into four categories of hyperplasia - low, moderate, severe, and adenocarcinoma ${ }^{3}$. Low and moderate hyperplasias were characterized by discrete architectural alterations in glands, presenting variable volume, irregular shapes and frequent cystic transformations (Figure 1). Glandular epithelium showed proliferative endometrial characteristics and some mitotic indicators. Stromal cells proliferated too; there was not glandular juxtaposition. The distinction between low and moderate hyperplasia was made according to the number of dilated glands, their volumes and the final endometrial thickness.

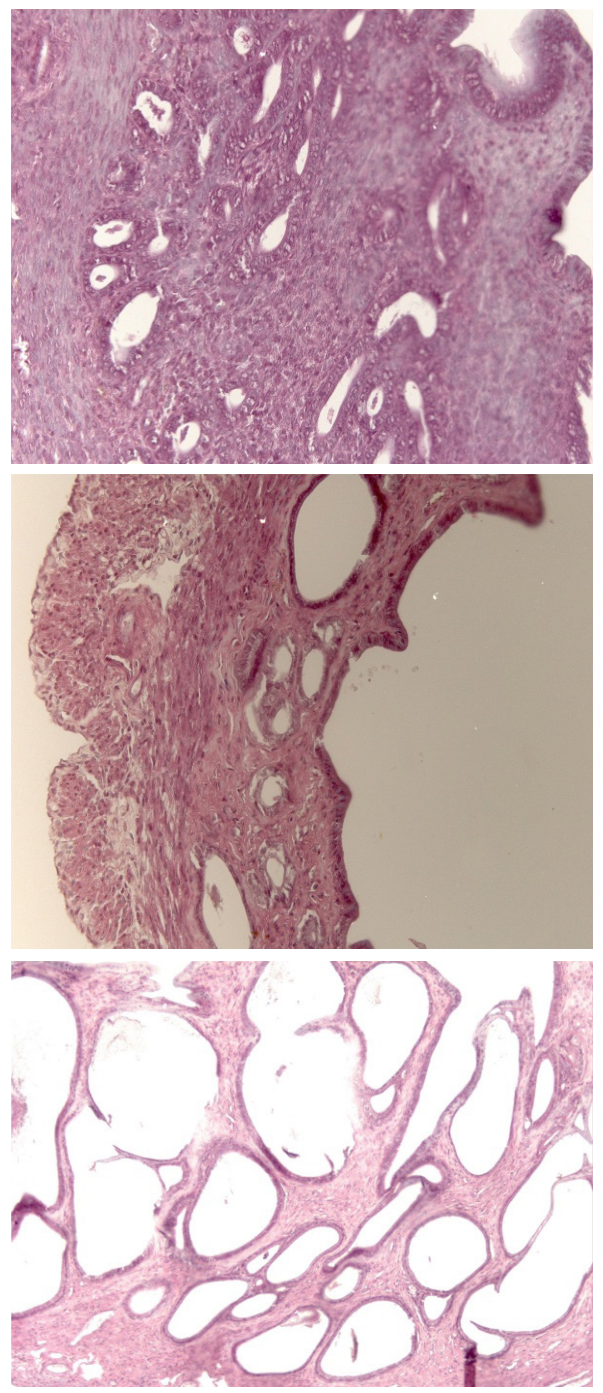

FIGURE 1 - Photomicrographs of uterine slices. Normal endometrium (A), low hyperplasia (B), and moderate hyperplasia (C). H\&E, x200 and $\mathrm{x} 400$.
Classification criteria for severe hyperplasia included high epithelial proliferation in the glands with stratification and cellular atypias, besides the irregular shape of the glands. Adenocarcinoma was classified based on intense and irregular gland proliferation and its juxtaposition (without circumjacent stroma), atypical covering and muscular layer invasion.

\section{Statistic analysis}

Data were collected, digitalized in SPSS for Windows 16.0 software (SPSS Inc., Chicago, IL, USA). Differences between groups were evaluated with student's $t$ test and ANOVA (hormone levels) and chi-square test (histological analysis). Statistical significance was considered for $p<0.05$. The sample group of 12 mice per group was enough to evaluate differences superior to $55 \%$ for endometrial proliferative lesion proportions (confidence interval $=95 \%$ and statistical power $80 \%$ ).

\section{Results}

During the experiment, three deaths were recorded: two animals from Group II (ENU + EHB) and one animal from Group $\mathrm{IV}(\mathrm{ENU}+\mathrm{EHB}+\mathrm{Ltz})$.

\section{Hormone quantification}

As illustrated in Figure 2, group II (ENU + EHB) showed higher serum levels of E2 compared to the group I (control) $(63.0 \pm 4.8$ vs. $26.0 \pm 0.3 \mathrm{pg} / \mathrm{mL} ; \mathrm{p}<0.05)$. E2 levels in groups III $(\mathrm{ENU}+\mathrm{EHB}+\mathrm{MPA})(59.42 \pm 3.4 v s .26 .0 \pm 0.3 \mathrm{pg} / \mathrm{mL} ; \mathrm{p}<0.05)$ and $\mathrm{IV}(\mathrm{ENU}+\mathrm{EHB}+\mathrm{Ltz})(57.72 \pm 1.2$ vs. $26.0 \pm 0.3 \mathrm{pg} / \mathrm{mL} ; \mathrm{p}<0.05)$ were higher too, statistically similar to group II (ENU + EHB).

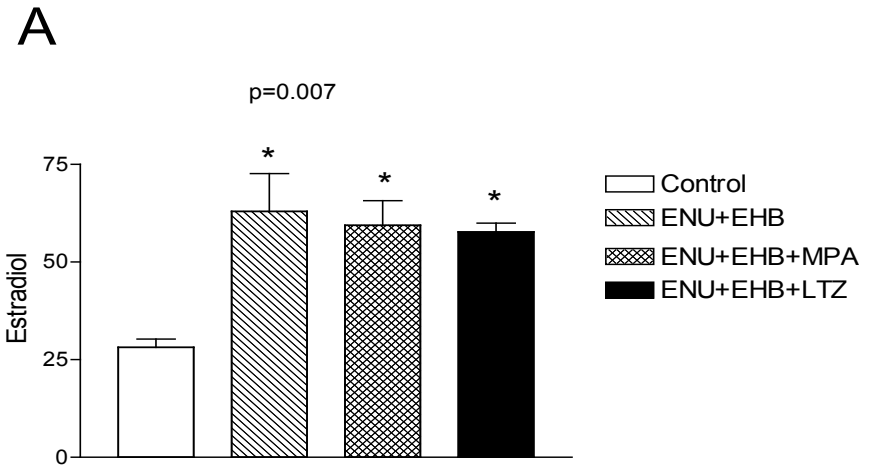

FIGURE 2 - Serum hormone levels in mice submitted to estrogen+carcinogen induced endometrial hyperplasia.

Note: ENU-N-ethyl-N-nitrosourea, HEB-Estradiol Hexahydrobenzoate, MPA-Medroxy Progesterone Acetate, Ltz-Letrozole. Bars are average \pm SEM. *p $<0.05$ vs. control group (I); $\# \mathrm{p}<0.05$ vs. group III (ANOVA or student's t test). 


\section{Histological evaluation}

No endometrial hyperplasia was evident in 27 animals, however low hyperplasia was detected in 5 animals, and moderate hyperplasia was detected in 13 animals. We did not register animals with severe hyperplasia or endometrial adenocarcinoma (Table 2).

TABLE 2 - Incidence and classification of endometrial proliferative lesions, and summary of treatments.

\begin{tabular}{|c|c|c|c|c|c|}
\hline \multirow{2}{*}{$\begin{array}{c}\text { Experimental } \\
\text { Groups }\end{array}$} & \multirow[b]{2}{*}{$\mathrm{N}$} & \multicolumn{4}{|c|}{ Hyperplasia } \\
\hline & & No & Low & Moderate & $\begin{array}{l}\text { Se- } \\
\text { vere }\end{array}$ \\
\hline I (control) & 12 & $\begin{array}{c}12 \\
(100 \%)\end{array}$ & 0 & 0 & 0 \\
\hline $\begin{array}{c}\text { II (EN- } \\
\mathrm{U}+\mathrm{EHB})\end{array}$ & 10 & $3(30 \%) *$ & 0 & $7(70 \%)^{*}$ & 0 \\
\hline $\begin{array}{c}\text { III (ENU+ } \\
\text { EHB +MPA) }\end{array}$ & 12 & $\begin{array}{c}7 \\
(58.3 \%)^{*}\end{array}$ & $\begin{array}{c}5 \\
(41.7 \%) * !\end{array}$ & 0 & 0 \\
\hline $\begin{array}{l}\text { IV (ENU+ } \\
\text { EHB +Ltz) }\end{array}$ & 11 & $\begin{array}{c}5 \\
(45.4 \%) *\end{array}$ & 0 & $\begin{array}{c}6 \\
(54.6 \%)^{*} \#\end{array}$ & 0 \\
\hline
\end{tabular}

ENU - N-ethyl-N-nitrosourea, HBE - Estradiol Hexahydrobenzoate MPA - Medroxy Progesterone Acetate, Ltz - Letrozole. * $\mathrm{p}<0.05$ vs. control group (I); $\mathrm{p}<0.05$ vs. group II; $\# \mathrm{p}<0.05$ vs. group III.I $x$ II groups: $\mathrm{p}=0.001$; I $x$ III groups: $\mathrm{p}=0.037$; I $x$ IV: groups $\mathrm{p}=0.005$; II $x$ III groups: $\mathrm{p}=0.001$; II $x$ IV groups: $\mathrm{p}=0.659$; III $x$ IV groups Group 3 vs. 4: $\mathrm{p}=0.003$ (qui square test).

Endometrial hyperplasia, or any sign of endometrial proliferative lesion, was not detected in group I (control). A higher incidence of hyperplasic lesions was observed in group II (ENU + EHB) compared to group I. When compared to group III (ENU + $\mathrm{EHB}+\mathrm{MPA})$, group II (ENU + EHB) showed a higher incidence and degree of this kind of lesion $(70 \%$ of moderate hyperplasia and $30 \%$ of the cases with uterine cavity edema and endometrial atrophy, without hyperplasia) (Table 3). The incidence of low proliferative lesions was significantly higher too, compared to group I (control) $(\mathrm{p}<0.05)$. There was no statistical difference for the occurrence of endometrial hyperplasia between groups II (ENU $+\mathrm{EHB})$ and IV $(\mathrm{ENU}+\mathrm{EBH}+\mathrm{Ltz})$. In group III $(\mathrm{ENU}+\mathrm{EHB}+$ MPA), we observed the highest rate of hyperplasia, compared to group I (control) $(\mathrm{p}<0.05)$.
TABLE 3 - Summary of experimental models of induction of hyperplasic lesions and endometrial cancer.

\begin{tabular}{|c|c|c|c|}
\hline Author & Drugs & Time & Results \\
\hline Takahashi $^{19}$ & ENU & 16 weeks & $69 \%$ adenocarcinoma \\
\hline Takahashi ${ }^{24}$ & $\begin{array}{c}\text { ENU } \\
\text { ENU+ E }\end{array}$ & $\begin{array}{l}15 \text { weeks } \\
15 \text { weeks }\end{array}$ & $\begin{array}{c}68 \% \text { hyperplasia } \\
8 \% \text { adenocarcinoma } \\
64 \% \text { hyperplasia } \\
36 \% \text { adenocarcinoma }\end{array}$ \\
\hline Niwa $^{8}$ & $\begin{array}{l}\text { MNU+E+ } \\
\text { MPA } \\
\text { MNU+E } \\
\text { MNU } \\
\text { MPA }\end{array}$ & $\begin{array}{l}30 \text { weeks } \\
30 \text { weeks } \\
30 \text { weeks } \\
30 \text { weeks }\end{array}$ & $\begin{array}{c}13 \% \text { hyperplasia }^{\mathrm{a}} \\
7 \% \text { adenocarcinoma } \\
67 \% \text { hyperplasia }^{\mathrm{a}} \\
33 \% \text { adenocarcinoma } \\
27 \% \text { hyperplasia } \\
\text { a } \\
12 \% \text { adenocarcinoma } \\
0 \% \text { hyperplasia } \\
0 \% \text { adenocarcinoma }\end{array}$ \\
\hline Niwa $^{21}$ & $\begin{array}{l}\text { MNU } \\
\text { MNU }\end{array}$ & $\begin{array}{l}23 \text { weeks } \\
30 \text { weeks }\end{array}$ & $\begin{array}{l}7 \% \text { adenocarcinoma } \\
12 \% \text { adenocarcinoma }\end{array}$ \\
\hline Ando- $\mathrm{Lu}^{20}$ & ENNG & $\begin{array}{c}12 \\
\text { months }\end{array}$ & $\begin{array}{c}40 \% \text { hyperplasia } \\
49 \% \text { adenocarcinoma }\end{array}$ \\
\hline $\begin{array}{l}\text { Newbold }^{18} \\
\text { and Liehr }\end{array}$ & $\begin{array}{l}\text { 4-Hydroxies- } \\
\text { tradiol } \\
\text { 17-ßestradiol }\end{array}$ & $\begin{array}{c}18 \\
\text { months }\end{array}$ & $\begin{array}{l}66 \% \text { adenocarcinoma } \\
7 \% \text { adenocarcinoma }\end{array}$ \\
\hline $\begin{array}{l}\text { Present } \\
\text { study }\end{array}$ & $\mathrm{ENU}+\mathrm{E}$ & $\begin{array}{c}16 \\
\text { months }\end{array}$ & $\begin{array}{l}70 \% \text { hyperplasia } \\
\text { moderate }\end{array}$ \\
\hline
\end{tabular}

MNU - N-methyl-N- nitrosourea; ENNG - N-ethyl-N'- nitrosogranidina; ENU - N-ethyl-N- nitrosourea; E-estrogen; MPA - Medroxy Progesterone Acetate ${ }^{a}$ Atypic Hyperplasia

However, the degree of hyperplasia in group III (ENU $+\mathrm{EHB}+\mathrm{MPA})$ was significantly lower than groups II (ENU + $\mathrm{EHB})$, and IV (ENU + EHB + Ltz) $(\mathrm{p}<0.05)$, showing normal glands and few dilated glands and lower endometrial proliferation. For group IV (ENU + EHB + Ltz), we observed a higher rate of endometrial hyperplasia when compared to groups I (control) and III $(\mathrm{ENU}+\mathrm{EHB}+\mathrm{MPA})(\mathrm{p}<0.05)$, but it was statistically similar to group II (ENU + EHB), $(\mathrm{p}>0.05)$.

\section{Discussion}

The present study showed that $70 \%$ of mice developed moderate hyperplasia after 16 weeks of ENU + EHB exposure. Similarly to the previously cited study, we obtained cases of estrogen-stimulated and carcinogen-initiated hyperplasia. We did not observe cases of endometrial adenocarcinoma, which could be justified by the short period of drug exposition or to the lower dose of carcinogen used, as discussed previously. 
Several experimental studies have described models of conventional or genetically modified animals, tumoral inoculation or tumor induction with the administration of endometrial tumor inducers and/or tumor-promoting drugs. The methodology of the present study was based in the work of Takahashi et al. ${ }^{24}$, who developed an experimental model of endometrial adenocarcinoma induction in 11 week-old female CD-1 mice through intrauterine injection of ENU associated with estrogen for 16 weeks.

Progesterone administration was associated with a low rate of endometrial hyperplasia, compared to the other experimental groups. The hyperplasia observed in this group was lower in degree, with fewer dilated glands and lower epithelial proliferation, possible evidence for a progesterone protective action to the carcinogen+estrogen-induced endometrial proliferation. Niwa et al. ${ }^{8}$ observed no similar results about the incidence of endometrial proliferative lesions, with rates of $7 \%$ in progesterone-treated groups and 33\% in the group that received carcinogen+estrogen only. The same investigators observed an inhibitory effect of MPA, reducing the incidence of endometrial cancer, atypical hyperplasia or adenomatous hyperplasia in those animals ${ }^{8}$.

Letrozole-treated groups showed a similar endometrial pattern to the group that received only ENU + EHB; there was no evidence that aromatase inhibition could protect endometrium in the present study. Other studies, such as Brodie et al. ${ }^{22}$ and Long et al. ${ }^{23}$, compared tamoxifen and letrozole actions in human breast carcinoma-derived tumors inoculated in ovariectomized female $\mathrm{BALB} / \mathrm{c}$ mice. Tumor growth was suppressed in both groups that received tamoxifen or letrozole, supporting that these drugs could be effective inhibitors for the tumor growth through local estrogenic stimulus.

Jongen et al. ${ }^{16}$ evaluated the effect of the same aromatase inhibitor in histocultures of endometrioid endometrial cancer with evidence of estrogen depletion in the tumoral site, which could result in diminished tumoral cellular proliferation. In contrast with tamoxifen, aromatase inhibitors do not induce adverse effects, such as neoplasia or endometrial hyperplasia.

In the Tulay Kilic-Okman et al. ${ }^{13}$ investigation, the effects of letrozole were compared to that caused by clomiphene citrate in rat ovarian follicles, endometrium and hormonal levels. Oral letrozole suppressed blood and urinary estrogenic levels and caused similar effects to clomiphene citrate in the follicular growth stimulation. Endometrial thickness was similar between the groups; supporting the idea that letrozole could have direct antiestrogenic effects in the endometrium.
The issue of how to extrapolate animal data to human remains profoundly difficult. Data from clinical studies regarding the endometrial effects of letrozole in women is controversial. In 1984, Tseng et al. ${ }^{25}$ obtained objective results using aromatase inhibitors for women with advanced endometrial cancer; aromatase inhibitors were able to inhibit aromatase in these tumors, in vivo. However, the beneficial use of these drugs in well-differentiated endometrial tumors or in hormone receptor positive tumors as an adjuvant therapy is still uncertain. Boeddinghaus and Dowsett ${ }^{26}$ reported that few studies have evaluated the effect of aromatase inhibitors in pre-menopausal women; such as letrozole, failed to show suppressed estrogenic levels. Nevertheless, Barker et al. ${ }^{27}$ investigated the role for aromatase inhibitors in the treatment of endometrial hyperplasia and endometrial adenocarcinoma in postmenopausal women not amenable to surgical treatment. These drugs were associated to a decreased of $81.7 \%$ in endometrial thickness in patients with endometrial hyperplasia.

In cited studies, aromatase inhibitor drugs were used in the experimental treatment of tumors, in vivo or in vitro, but there was no approach for their action in carcinogenic process of endometrium. We expected that the dose of letrozole we used could act as a protective antiestrogenic agent in the process of inducing endometrial proliferative lesions, but this action was not observed in our study. We could suppose that letrozole does not act as an inhibitor of exogenous endometrial estrogenic function. The estradiol dose was identical for all the experimental groups, which confirms that letrozole was not able to diminish serum estradiol levels in group IV $(\mathrm{ENU}+\mathrm{EHB}+\mathrm{Ltz})$.

Data for the group that received a progestagenic compound - MPA - showed a protective role for this drug for endometrial proliferation. Curiously, this action was not observed in the letrozole-treated group, where no evidence of endometrial proliferative protection was detected. Letrozole has been used in breast and endometrium malignant tumors already installed, with evidences that could exist estrogenic depletion in tumoral site by aromatase inhibition ${ }^{28}$. This action was not supported by the present study. We evaluated the effect of this drug in the process of endometrial proliferative induction utilizing exogenous estrogen. This could justify the lack of inhibition of this kind of lesion by letrozole.

Experimental evaluations of the endometrial carcinogenesis process are limited for many clinical, technical and ethical reasons. One of the strengths of this study is the novelty of evaluating the endometrial effects of Ltz in a carcinogen+estrogeninduced endometrial hyperplasia experimental model. The problem 
studied here is very complex and this study also has limitations as the definition of the experimental model regarding the dose of the drugs used, the time of stimulation and the classification of the endometrial lesions originally described in women. Another limitation of the present study is how to extrapolate animal data to human. However, a better understanding of the intratumoral action of aromatase in estrogenic-dependent malignant tumors, such as endometrioid endometrial carcinoma, could contribute to the potential development of endocrine therapy with aromatase inhibitors.

\section{Conclusions}

Medroxy progesterone acetate partially inhibited the development of endometrial proliferative lesions in mice with ENU+HBE-induced endometrial hyperplasia. There was no evidence that letrozole could act as an antiestrogenic drug in the development of these endometrial proliferative lesions.

\section{References}

1 Horn LC, Meinel A, Handzel R, Einenkel J. Histopathology of endometrial hyperplasia and endometrial carcinoma: an update. Ann Diagn Pathol. 2007;11(4):297-311. PMID: 17630117.

2 Horn LC, Schnurrbusch U, Bilek K, Hentschel B, Einenkel J. Risk of progression in complex and atypical endometrial hyperplasia: clinicopathologic analysis in cases with and without progestogen treatment. Int J Gynecol Cancer. 2004;14(2):348-53. PMID: 15086736 .

3 Hasegawa K, Nagao S, Yasuda M, Millan D, Viswanathan AN, Glasspool RM, Devouassoux-Shisheboran M, Covens A, Lorusso D, Kurzeder C, Kim JW, Gladieff L, Bryce J, Friedlander M, Fujiwara $\mathrm{K}$. Gynecologic Cancer InterGroup (GCIG) consensus review for clear cell carcinoma of the uterinecorpus and cervix. Int J Gynecol Cancer. 2014 Nov;24(9 Suppl 3):S90-5. PMID: 25341588.

4 Mazzon I, Scotto V, Guidi ML, Vittori G, Ricci G, Crisci G, et al. Outpatient hysteroscopy in the diagnosis of neoplastic and preneoplastic lesions of the endometrium. Eur J Gynaecol Oncol. 1988;9(3):261-4. PMID: 3391199.

5 Nagele F, O'Connor H, Davies A, Badawy A, Mohamed H, Magos A. 2500 Outpatient diagnostic hysteroscopies. Obstet Gynecol. $1996 \mathrm{Jul} ; 88(1): 87-92$.

6 van Hanegem N, Prins MM, Bongers MY, Opmeer BC, Sahota DS, Mol BW, Timmermans A. The accuracy of endometrial sampling in women with postmenopausal bleeding: a systematic review and meta-analysis. Eur J Obstet Gynecol Reprod Biol. 2016;197:147-55. PMID: 26748390.

7 Hannemann MM, Alexander HM, Cope NJ, Acheson N. Endometrial hyperplasia: a clinician's review. Obstet Gynaecol Reprod Med. 2007;17:169-72. doi: 10.1016/j.ogrm.2007.04.006.

8 Niwa K, Morishita S, Murase T, Itoh N, Tanaka T, Mori H, Tamaya $\mathrm{T}$. Inhibitory effects of medroxyprogesterone acetate on mouse endometrial carcinogenesis. Jpn J Cancer Res. 1995;86(8):724-9. PMID: 7559094.

9 Dahhan T, Fons G, Buist MR, Ten Kate FJ, van der Velden J. The efficacy of hormonal treatment for residual or recurrent low-grade endometrial stromal sarcoma. A retrospective study. Eur J Obstet Gynecol Reprod Biol. 2009;144:80-4. PMID: 19269732.

10 Nakayama K, Ishikawa M, Nagai Y, Yaegashi N, Aoki Y, Miyazaki $\mathrm{K}$. Prolonged long-term survival of low-grade endometrial stromal sarcoma patients with lung metastasis following treatment with medroxyprogesterone acetate. Int J Clin Oncol. 2010;15:179-83. PMID: 20217451.

11 Amant F, Floquet A, Friedlander M, Kristensen G, Mahner S, Nam EJ, Powell MA, Ray-Coquard I, Siddiqui N, Sykes P, Westermann AM, Seddon B. Gynecologic Cancer InterGroup (GCIG) consensus review for endometrial stromal sarcoma. Int $\mathrm{J}$ Gynecol Cancer. 2014;24:S67-72. PMID: 25033257.

12 Jordan VC. Medroxyprogesterone acetate and metastases: of mice and (wo)men. J Natl Cancer Inst. 2005;97:619-21. PMID: 15870426.

13 Kilic-Okman T, Kucuk M, Altaner S. Comparison of the effects of letrozole and clomiphene citrate on ovarian follicles, endometrium, and hormone levels in the rat. Fertil Steril. 2003;80(6):1330-2. PMID: 14667861.

14 Reich O, Regauer S. Hormonal therapy of endometrial stromal sarcoma. Curr Opin Oncol. 2007;19:347-52. PMID: 17545798.

15 Geisler J. Differences between the non-steroidal aromatase inhibitors anastrozole and letrozoleVof clinical importance? Br J Cancer. 2011;104:1059-66. PMID: 21364577.

16 Jongen VH, Sluijmer AV, Heineman MJ. The postmenopausal ovary as an androgen-producing gland; hypothesis on the etiology of endometrial cancer. Maturitas. 2002;43(2):77-85. PMID: 12385855.

17 Ito K. Hormone replacement therapy and cancers: the biological roles of estrogen and progestin in tumorigenesis are different between the endometrium and breast. Tohoku J Exp Med. 2007;212(1):1-12. PMID: 17464097.

18 Steed HL, Chu QS. Aromatase inhibition: a potential target for the management of recurrent or metastatic endometrial cancer by letrozole: more questions than answers? Expert Opin Investig Drugs. 2011;20(5):681-90. PMID: 21413907.

19 Takahashi M, Iijima T, Suzuki K, Ando-Lu J, Yoshida M, Kitamura T, Nishiyama K, Miyajima K, Maekawa A. Rapid and high yield induction of endometrial adenocarcinomas in CD-1 mice by a single intrauterine administration of N-ethyl-N-nitrosourea combined with chronic 17 beta-estradiol treatment. Cancer Lett. 1996 Jun 24;104(1):7-12. PMID: 8640748.

20 Newbold RR, Liehr JG. Induction of uterine adenocarcinoma in CD-1 mice by catechol estrogens. Cancer Res. 2000 Jan 15;60(2):235-7. PMID: 10667565.

21 Niwa K, Morishita S, Murase T, Mudigdo A, Tanaka T, Mori H, Tamaya T. Chronological observation of mouse endometrial carcinogenesis induced by N-methyl-N-nitrosourea and 17 betaestradiol. Cancer Lett. 1996 Jun 24;104(1):115-9. PMID: 8640737.

22 Brodie A, Lu Q, Yue W, Wang J, Liu Y. Intratumoral aromatase model: the effects of letrozole (CGS 20267). Breast Cancer Res Treat. 1998;49 Suppl 1:S23-6; discussion S33-7. PMID: 9797014.

23 Long BJ, Jelovac D, Handratta V, Thiantanawat A, MacPherson N, Ragaz J, Goloubeva OG, Brodie AM. Therapeutic strategies using the aromatase inhibitor letrozole and tamoxifen in a breast cancer model. J Natl Cancer Inst. 2004 Mar 17;96(6):456-65. PMID: 15026471 .

24 Takahashi M, Nishimura S, Miyajima K, Sasahara K, Yoshida M, Ando J, Maekawa A.. Time-dependent promotion activity of 17betaestradiol on uterine carcinogenesis in mice initiated with N-ethylN-nitrosourea. Cancer Lett. 2001 Apr 26;165(2):123-30. PMID: 11275360 .

25 Tseng L, Mazella J, Funt MI, Mann WJ, Stone ML. Preliminary studies of aromatase in human neoplastic endometrium. Obstet Gynecol. 1984 Feb;63(2):150-4. PMID: 6694807. 
26 Boeddinghaus IM, Dowsett M. Comparative clinical pharmacology and pharmacokinetic interactions of aromatase inhibitors. J Steroid Biochem Mol Biol. 2001 Dec;79(1-5):85-91. PMID: 11850211.

27 Barker LC, Brand IR, Crawford SM. Sustained effect of the aromatase inhibitors anastrozole and letrozole on endometrial thickness in patients with endometrial hyperplasia and endometrial carcinoma. Curr Med Res Opin. 2009 May;25(5):1105-9. PMID: 19301987.

28 Ma BB, Oza A, Eisenhauer E, Stanimir G, Carey M, Chapman W, Latta E, Sidhu K, Powers J, Walsh W, Fyles A. The activity of letrozole in patients with advanced or recurrent endometrial cancer and correlation with biological markers--a study of the National Cancer Institute of Canada Clinical Trials Group. Int J Gynecol Cancer. 2004 Jul-Aug;14(4):650-8. PMID: 15304161.

\section{Correspondence:}

Ana Luiza Lunardi Rocha

Departamento de Obstetricia e Ginecologia, UFMG

Avenida Professor Alfredo Balena 190

30.130-100 Belo Horizonte - MG Brasil

Tel.: (55 31)3409-89764

Fax: (55 31)-34099765

ana_lunardi@yahoo.com.br

Received: Dec 05, 2015

Review: Feb 09, 2016

Accepted: Mar 11, 2016

Conflict of interest: none

Financial source: none

${ }^{1}$ Research performed at Department of Obstetrics and Gynecology, Universidade Federal de Minas Gerais (UFMG), Belo Horizonte-MG, Brazil. 